Dept. of Parasitology,

Fac. of Vet. Med., Beni-Suef Univ.

\title{
DETERMINATION OF COMMON EPITOPES BETWEEN TOXOCARA VITULORUM AND TOXOCARA CANIS AS A PRELIMINARY STUDY FOR VACCINE PRODUCTION
}

(With 2 Tables and One Plate)

\section{By}

\section{M.A. EL-ASKALANY; KH.M. EL-DAKHLY and H.S. LOTFY*}

* Animal Health Research Institute, Beni-Suef branch.

(Received at 14/5/2008)

تعيين المولدات المضادة المتخصصة والمشتركة بين توكسوكارا الأبقار

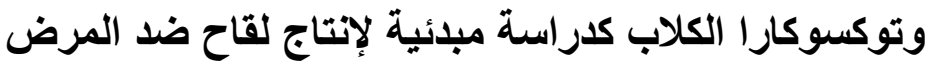

\section{محمود أمبن مصطفي العسقلانسي ، خالد محمد اللاخلي ، حسين سبي لطفي}

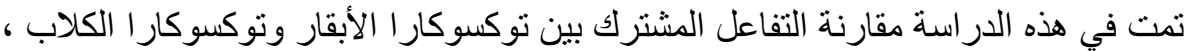

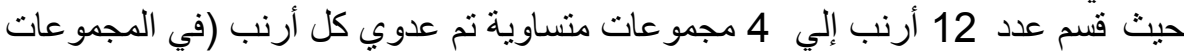

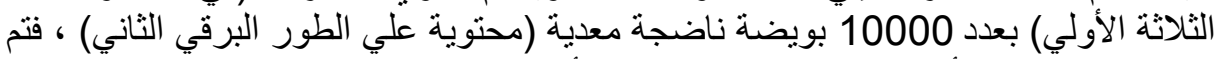

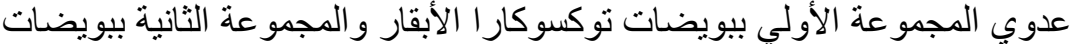

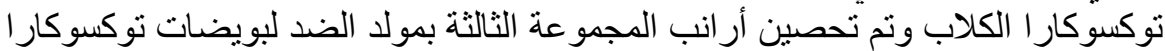

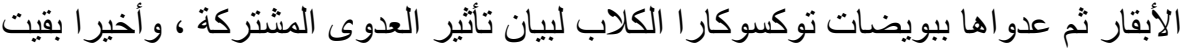

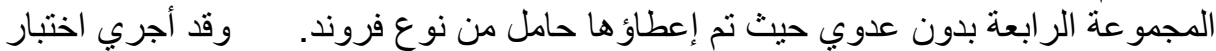

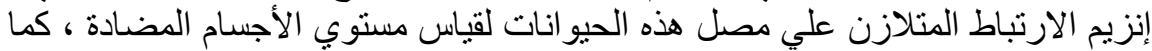

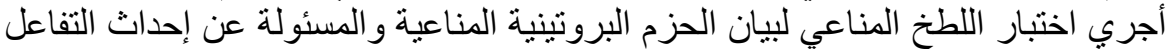

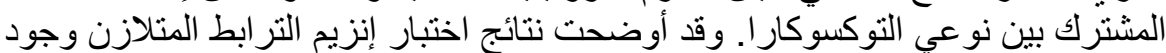

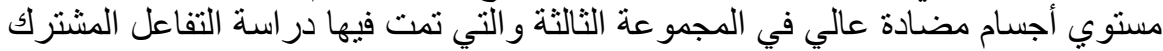

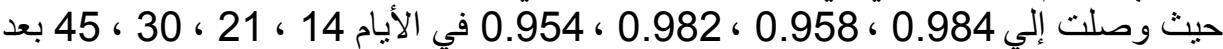

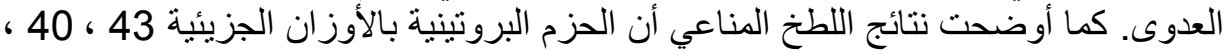

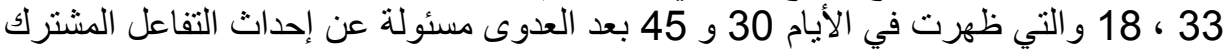
بين توكسوكار الأبقار وتوكسوكار الكابل الكلاب.

\section{SUMMARY}

In this study, cross reactivity between Toxocara vitulorum (T. vitulorum) and Toxocara canis (T. canis) was evaluated. Twelve rabbits were divided into 4 equal groups; the first was infected with embryonated 
T. vitulorum eggs (10000 embryonated eggs for each rabbit); the second was infected with the same dose of $T$. canis, the third was immunized with $T$. vitulorum antigen and challenged with $T$. canis and the fourth group given Freund's adjuvant as a control negative group. All these groups were tested by ELISA for detection of serum antibodies. Furthermore, Western Blot was applied to determine the common epitopes between the two species of Toxocara. ELISA results revealed that, the mean positive antibody titres recovered from the third group were (0.984), (0.958), (0.982) and (0.954) at the days 14, 21, 30 and 45 p.i respectively. Moreover, immunoblotting revealed that protein bands of molecular weights $43,40,33$, and $18 \mathrm{kDa}$ respectively at the days 30 and 45 p.i, were common between Toxocara vitulorum and Toxocara canis. From these bands, prospective vaccine production against toxocariasis could be done.

Key words: Toxocara vitulorum, Toxocara canis, epitopes, vaccine, rabbits.

\section{INTRODUCTION}

Toxocariasis is considered as one of the important parasitic diseases which constitute a huge public health problem all over the world (Morales et al., 2002). The disease is caused by the nematodal helminth of Toxocara spp. including $T$. canis which frequently present in the small intestine of dogs and T. vitulorum which inhabits the intestine of buffalo calves (Soulsby, 1982).

Life cycle of Toxocara species is so complicated, via which larvae of $T$. vitulorum in white mice for example, manifested a migratory behavior similar to other ascarids. The main route for migration of $T$. vitulorum larvae in buffaloes is from the gut to the liver by passive blood transport through the portal vein and in a minor way, through mesenteric lymph nodes (Roberts et al., 1990). Moreover, migration of $T$. canis larvae through tissues produces pathological changes as well as the larvae became widely disseminated throughout the body, where they could live either encapsulated and/or free in the brain for long periods (Glickman and Summers, 1983). Description of the lesions and migratory patterns of $T$. canis in pigs were studied by (Sommerfelt et al., 2004).

Since the diagnosis of visceral larva migrans is too difficult, immunological methods are required, although little is known about immunity of $T$. vitulorum (Amerasinghe et al., 1984). 
The cross reactions were especially prominent between Toxocara species, a fact further substantiated when reactivity of $T$. canis E/Sspecific monoclonal antibodies were tested against $T$. leonina and T. vitulorum antigens. The majority of antibodies precipitated antigens of T. vitulorum (Page et al., 1991). Currently, ELISA is being used to detect IgG antibody against Toxocara spp. by using the excretory/secretory antigen (E/S) with high sensitivity results, followed by identification of the parasite proteins of this antigen which induced the immune response by the Western blot (Morales et al., 2002). Moreover, Ashour et al. (1995) demonstrated the degree of homogeneity and heterogeneity of the ascaridid nematodes with SDS-PAGE protein patterns.

The aim of the present work was to determine the most common epitopes between Toxocara vitulorum and Toxocara canis that could be applied as a preparatory and feasible step for vaccine production.

\section{MATERIALS and METHODS}

\section{Collection and embryonation of eggs:}

Toxocara vitulorum adult worms were obtained from small intestine of the slaughtered buffalo calves at Beni-Suef abattoirs, washed several times with saline and examined microscopically. Fertile eggs were obtained from gravid females using blunt scissor, sieved, washed and sedimented several times using $1 \%$ formol-saline followed by refrigerating in adequate solution till use (Sabry, 1999). Similarly, sacrificed puppies were eviscerated and dissected, then Toxocara canis adult gravid females were collected from small intestine. Fertile eggs were collected, put in clean Petri dishes containing normal saline, followed by washing and finally examined microscopically.

The collected eggs were divided into several amounts put in clean Petri-dishes and incubated at $28{ }^{\circ} \mathrm{C}$, exposed to several rewashing and good aeration, microscopically examined to observe the developmental changes and left to embryonate for 30 days (Omar and Barriga, 1991 and Mousa et al., 2001). Some of the embryonated eggs were used for antigen preparation, and others were kept at $4{ }^{\circ} \mathrm{C}$ for challenge.

\section{Preparation of Toxocara vitulorum antigen:}

The embryonated infective T. vitulorum eggs were washed several times with $0.01 \mathrm{M}$ PBS (pH 7.4) by centrifugation at $1500 \mathrm{rpm}$ 
for 10 minutes to remove remnants of the formol-saline. Eggs were mixed with an equal volume of the solution, then homogenized at 6000 rpm for 5 minutes in ice bath. The homogenized samples were sonicated for 5 minutes at 5 pulse rate and 60-80 amplitude value using Cole Parner ultra sonic sonicator. Then the suspension was subjected to high speed centrifugation $14,000 \mathrm{rpm}$ at $4{ }^{\circ} \mathrm{C}$ for 30 minutes. The supernatant fluid containing soluble antigenic materials was separated and stored at $20{ }^{\circ} \mathrm{C}$ in plastic vials till used (Sabry, 1999 and Arafa, 2008). Protein content of the antigenic components was determined according to Lowry et al. (1951).

\section{Rearing and housing of rabbits:}

Twelve male New Zealand healthy rabbits of an average one $\mathrm{kg}$ body, reared in clean and disinfected batteries and fed on maintenance ration provided with anti-coccidial drugs. Temperature and ventilation were adjusted.

\section{Experimental design:}

\subsection{Grouping of animals:}

Rabbits were divided into 4 equal groups:

- Group A (Rabbits infected with T. vitulorum).

- Group B (Rabbits infected with T. canis).

- Group $C$ (Rabbits immunized with $T$. vitulorum antigen and challenged with $T$. canis).

- Group D (Rabbits administered Freund's adjuvant as a negative control).

\subsection{Protocol of immunization:}

Rabbits of group (C) were immunized with $T$. vitulorum antigen in Freund's adjuvant according to the method described by Mousa et al. (2001).

\subsection{Procedure of infection:}

Each rabbit was infected with 10000 embryonated T. vitulorum or $T$. canis eggs (according to the group) orally using stomach tube.

\subsection{Blood collection:}

Blood was collected from the ear veins at the days 14, 21, 30 and 45 p.i., then serum was obtained by centrifugation and preserved at $20^{\circ} \mathrm{C}$ till use. 


\section{Diagnostic tools:}

\subsection{Enzyme-linked immunosorbent assay (ELISA):}

ELISA was applied to detect antibodies against $T$. vitulorum antigen using 96-well flat microtiter plate according to Starke-Buzetti et al. (2001) and Arafa (2008).

\subsection{Sodium Dodecyl Sulphate PolyAcrylamide Gel Electrophoresis: (SDS-PAGE):}

It was used for determination of molecular weights of polypeptide bands obtained by fractionation of antigen according to Laemmeli (1970).

\subsection{Western Blot technique:}

Polypeptide bands obtained from SDS-PAGE were electrophoretically transferred to nitrocellulose according Towbin et al. (1979) and the results were analyzed using Gel pro-analyzer 3.1.

\section{RESULTS}

1- Evaluation of both $T$. vitulorum and T. canis infection using ELISA:

ELISA was performed on sera of different rabbit groups (A, B, C and D) with $T$. vitulorum egg larval antigen at zero day (at the beginning of the experiment) and at the days 14, 21, 30 and 45 post infection (p.i.). The positively threshold value (considered as double fold of mean negative sera) was at O.D. (0.410). It has been found that, in group (A) the first mean antibody titre was found at the day 21 p.i. (0.496), reached the peak (0.657) at the day 30 p.i and reached (0.566) at the day 45 p.i. In group (B), the first mean antibody titre (0.463) was found at the day 30 p.i. and reached the peak (0.476) at the end of the experiment. Concerning the cross reaction between $T$. vitulorum egg antigen and serum of $T$.canis infected group (group C), there was a marked elevation in the mean antibody titre recording (0.984), (0.958), (0.982) and (0.954) at the days $14,21,30$ and 45 p.i respectively. In group (D), antibody titres were $0.480,0.598,0.778$ and 0.743 at the days $14,21,30$ and 45 p.i. (Table 1).

2- Reaction of $T$. vitulorum antigen with sera of infected (T. vitulorum and $T$. canis) groups:

Reaction of $T$. vitulorum antigen with sera of zero day of the experiment not show any bands, while the reaction of $T$. vitulorum antigen with sera of $T$. vitulorum infected group revealed bands of 
molecular weights 43, 40,33, 24, 22 and $18 \mathrm{kDa}$ at the day 30 p.i., the same bands appeared at the day 45 p.i. in addition to bands of 60 and 50 $\mathrm{kDa}$.

Reaction of $T$. vitulorum antigen with sera of $T$. canis infected group revealed polypeptide bands of molecular weights 55, 50, 43, 40, $33,24,22$ and $18 \mathrm{kDa}$ at the day 30 p.i., while bands of 50, 43, 40, 33 and $18 \mathrm{kDa}$ appeared at the day 45 p.i.

It's worthy to mention that polypeptide bands of molecular weights $43,40,33$, and $18 \mathrm{kDa}$ revealed from the reaction of $T$. vitulorum antigen with sera of both $T$. vitulorum and $T$.canis infected groups at both 30 and 45 day p.i.; so these bands were responsible for the cross reaction which was estimated by the ELISA (Table 2 and Plate 1).

Table 1: Evaluation of both T. vitulorum and T. canis infection using ELISA.

\begin{tabular}{|c|c|c|c|c|c|}
\hline \multicolumn{2}{|c|}{ Time } & Group (A) & Group (B) & Group (C) & Group (D) \\
\hline \multicolumn{2}{|c|}{ Zero day } & 0.206 & 0.142 & 0.199 & 0.208 \\
\hline \multirow{4}{*}{ 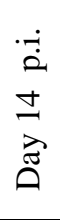 } & & 0.320 & 0.284 & 0.969 & 0.484 \\
\hline & & 0.399 & 0.291 & 0.993 & 0.475 \\
\hline & & 0.309 & 0.265 & 0.992 & 0.481 \\
\hline & Mean & 0.343 & 0.280 & 0.984 & 0.480 \\
\hline \multirow{4}{*}{$\begin{array}{l}\dot{-} \\
\overrightarrow{2} \\
\vec{N} \\
\overrightarrow{0}\end{array}$} & & 0.428 & 0.394 & 0.917 & 0.637 \\
\hline & & 0.563 & 0.387 & 0.984 & 0.624 \\
\hline & & 0.497 & 0.403 & 0.973 & 0.532 \\
\hline & Mean & 0.496 & 0.395 & 0.958 & 0.598 \\
\hline \multirow{4}{*}{$\begin{array}{l}\dot{-1} \\
\stackrel{0}{0} \\
\stackrel{n}{0} \\
\overrightarrow{0}\end{array}$} & & 0.750 & 0.454 & 0.971 & 0.753 \\
\hline & & 0.629 & 0.462 & 0.985 & 0.763 \\
\hline & & 0.592 & 0.473 & 0.990 & 0.818 \\
\hline & Mean & 0.657 & 0.463 & 0.982 & 0.778 \\
\hline \multirow{4}{*}{$\begin{array}{l}\dot{+} \\
\dot{0} \\
\stackrel{n}{+} \\
\vec{a} \\
\dot{a}\end{array}$} & & 0.615 & 0.472 & 0.921 & 0.757 \\
\hline & & 0.551 & 0.476 & 0.980 & 0.731 \\
\hline & & 0.531 & 0.479 & 0.962 & 0.742 \\
\hline & Mean & 0.566 & 0.476 & 0.954 & 0.743 \\
\hline
\end{tabular}

$*$ Cut off value $=0.410$ 
Table 2: Detection of specific epitopes revealed from reaction of Toxocara vitulorum antigen with sera of Toxocara species using Western Blot.

\begin{tabular}{|c|c|c|c|c|}
\hline$\frac{\dot{\bar{d}}}{\stackrel{a}{\vec{z}}}$ & $\begin{array}{l}\text { T. vitulorum antigen } \\
\text { with sera of } \\
\text { T. vitulorum infected } \\
\text { group (day } 30 \text { p.i.) }\end{array}$ & $\begin{array}{l}\text { T. vitulorum antigen } \\
\text { with sera of } \\
\text { T. vitulorum infected } \\
\text { group (day } 45 \text { p.i.) }\end{array}$ & $\begin{array}{l}T \text {.vitulorum antigen } \\
\text { with sera of } T . \text { canis } \\
\text { infected group } \\
\quad \text { (day } 30 \text { p.i.) }\end{array}$ & $\begin{array}{l}T \text {.vitulorum antigen } \\
\text { with sera of } T \text {. canis } \\
\text { infected group } \\
\text { (day } 45 \text { p. i.) }\end{array}$ \\
\hline \multicolumn{5}{|c|}{ ( } \\
\hline \multicolumn{5}{|l|}{160} \\
\hline \multicolumn{5}{|l|}{105} \\
\hline \multicolumn{5}{|l|}{75} \\
\hline & & 60 & & \\
\hline & & & 55 & \\
\hline \multirow[t]{3}{*}{50} & & 50 & 50 & 50 \\
\hline & 43 & 43 & 43 & 43 \\
\hline & 40 & 40 & 40 & 40 \\
\hline \multicolumn{5}{|l|}{35} \\
\hline & 33 & 33 & 33 & 33 \\
\hline \multicolumn{5}{|l|}{30} \\
\hline \multicolumn{5}{|l|}{25} \\
\hline & 24 & 24 & 24 & \\
\hline & 22 & 22 & 22 & \\
\hline & 18 & 18 & 18 & 18 \\
\hline \multicolumn{5}{|l|}{15} \\
\hline 10 & & & & \\
\hline
\end{tabular}

Plate 1: The common epitopes revealed from the reaction of $T$. vitulorum egg antigen with sera of both $T$. vitulorum and $T$. canis $\left(1,1^{*}\right.$ : Marker) 


\section{DISCUSSION}

Toxocariasis is one of the most important parasitic problems causing a major public health significance in different areas of the world. The residence of hypobiotic larvae in tissues of infected animals represent the main source of the parasitic persistence in domestic animals owing to migration of these larvae from the tissues of infected mothers to their offsprings via placenta or colostrum, and preceded by pulmonary migration to form adult ascarids in the intestine accompanied by shedding of large number of eggs in the environment.

Concerning to the phenomenon of cross reactivity between $T$. vitulorum antigen and serum of $T$. canis infected group, polypeptide bands of molecular weights $43,40,33$ and $18 \mathrm{kDa}$ showed cross reaction between Toxocara vitulorum and Toxocara canis in days 30 and 45 p.i. respectively, and these bands could be detected by using ELISA. These findings were enforced by those obtained by Page et al. (1991) who stated that the majority of $T$. canis monoclonal antibodies were precipitated against antigens of $T$. vitulorum.

Similar results were obtained by Safar et al. (1992) who estimated that the crude extract of $T$. vitulorum showed cross reaction with T.canis and Ascaris lumbricoides sera using double gel diffusion. In addition, Ashour et al. (1995) showed close relationship between T. vitulorum, Toxascaris leonina, Parascaris equorum and Toxocara canis, where protein extracts from adult worms of the four nematodes were resolved into a number of bands. Comparative analysis of dominant bands showed that 13 bands were common among the four species.

Moreover, Magnaval et al. (1991) suggested that the high molecular weight fractions were responsible for the cross reactivity. More or less similarity was obtained by Jacob (1995) who observed 4 bands between 29 and $210 \mathrm{kDa}$. Also these results were in accordance with those found by Sarimehmetoğlu et al. (2001) who applied western blot for immunodiagnosis of visceral larva migrans in mice. They revealed that specific protein bands for visceral larva migrans were determined as 24,28 , and $48 \mathrm{kDa}$.

On the other hand, Iddawela et al. (2007) revealed that there was no cross reaction between Toxocara vitulorum adult worm antigen and sera of $T$. canis E/S-57 antigen. This might be related to the difference in antigens used. 
It is worthy to mention that, a correlation between the band pattern and the stage of infection could be observed; as the antigenantibody reaction became visible on immunoblotting. Furthermore, a correlation between ELISA results and Western blot must be highlighted. These findings coincided with those revealed by Magnaval et al. (1991) and Morales et al. (2002).

The heterologus immunity between Toxocara species may be helpful for production of common vaccine used for protection against toxocariasis.

\section{REFERENCES}

Arafa, W.M. (2008): Some studies on Toxocara species in model experimental animal. M.V.Sc Thesis, Fac. Vet. Med. Beni-Suef Univ.

Amerasinghe, P.H.; Massodi, M.A.; Samarasinghe, B.; Sivanathan, S.; Gunawardana, V.K. and Fernando, S.T. (1984): Immunological responses of pregnant swam and Murrah buffalo cows and calves to Toxocara (Neoascaris) vitulorum infection. In: The use of nuclear techniques to improve domestic buffalo production in Asia. Int. Atomic Energy Agency, Vienna, Austria., 161-170.

Ashour, A.A.; Taha, H.A. and Mohammad, A.H. (1995): Comparative SDS-page protein patterns of four ascaridid nematodes. J Egypt Soc Parasitol.; 25 (3): 761-767.

Glickman, L.T. and Summers, B. (1983): Experimental Toxocara canis infection in cygonomolgus macaques (Macaca fascicularis). Am.J.Vet. Res., 44 (12): 2347-2354.

Iddawela, R.D.; Rajapakse, R.P.; Perera, N.A. and Agatsuma, T. (2007): Characterization of a Toxocara canis species-specific excretory-secretory antigen (TcES-57) and development of a double sandwich ELISA for diagnosis of visceral larva migrans. Korean J Parasitol., 45 (1): 19-26.

Jacob, C.M. (1995): Ánalise evolutiva dos parâmetros clínicolaboratorais da toxocaríase visceral na infância.São Paulo., (Tese de doutorado-Faculdade de Medicina da USP).

Laemmli, U.K. (1970): Cleavage of structural protein during the assembly of the head bacteriophage T4. Nature., 227: 680-685.

Lowry, O.H.; Rosenbrough, N.J.; Farr, A.L. and Randali, R.J. (1951): Protein measurement with Folin- phenol reagent. J. Biol. Chem., 193: 265-275. 
Magnaval, J.F.; Fabre, R.; Maurières, P.; Charlet, J.P. and de Larrard, B. (1991): Application of the western blotting procedure for the immunodiagnosis of human toxocariasis. Parasitol Res., 77(8):697-702.

Morales, O.L.; López, M.C.; Nicholls, R.S. and Agudel, C.O. (2002): Identification of Toxocara canis antigens by western blot in experimentally infected rabbits. Rev. Inst. Med .Trop. S. Paulo, 44 (4): 213-216.

Mousa, W.M.; Ezz El-Dien, N.M. and Ibrahim, S.F. (2001): Evaluation of three Toxocara canis antigens for serodiagnosis of experimentally infected rabbits with visceral larva migrans. J. Egypt. Vet. Med. Ass., 61 (1): 173-180.

Omar, H.M. and Barriga, O.O. (1991): Biology and pathophysiology of Toxocara vitulorum infections in a rabbit model. Vet. Parasitol., 40: 257-266.

Page, A.P.; Richards, D.T.; Lewis, J.W.; Omar, H.M. and Maizels, R.M. (1991): Comparison of isolates and species of Toxocara and Toxascaris by biosynthetic labelling of somatic and ES proteins from infective larvae. Parasitol., 103 (3): 451-464.

Roberts, J.A.; Fernando, S.T. and Sivanathan, S. (1990): Toxocara vitulorum in the milk of buffalo (Bubalus bubalis) cows. Res. Vet. Sci., 49 (3): 289-291.

Sabry, M.A. (1999): Epidemiological studies on Toxocariasis in animals and man. Ph.D. Vet. degree (zoonoses) Fac. Vet. Med., Cairo Univ.

Safar, E.H.; El-Rifaei, F. and Maklad, K.M. (1992): Protein chromatographic study on adult Ascaris lumbricoides, Ascaris vitulorum and Toxocara canis. J. Egypt Soc. Parasitol.,22 (1): 171-176.

Sarimehmetoğlu, H.O.; Burgu, A.; Aycicek, H.; Gönenç, B.; Tanyuksel, M. and Kara, M. (2001): Application of western blotting procedure for the immunodiagnosis of visceral larva migrans in mice by using excretory/secretory antigens. Dtsch Tierarztl Wochenschr., 108 (9): 390-392.

Sommerfelt, I.E.; Rosa, A.; Duchene, A.; Degregorio, O.; Lopez, C.; Pisanu, A. and De Torres, R. (2004): Toxocara canis in experimentally infected pigs. Migratory pattern and tissue lesions. Vet. Parasitol., 125: 323-334. 
Soulsby, E.J. (1982): Helminthes, Arthropoda and Protozoa of domesticated animals. 7th ed. Bailliere Tindal \& Casell Ltd. London.

Starke-Buzetti, W.A.; Machado, R.Z. and Zocoller-Seno, M.C. (2001): An enzyme-linked immunisorbent assay (ELISA) for detection of antibodies against Toxocara vitulorum in water buffaloes. Vet. Parasitol., 97 (1): 55-64.

Towbin, H.; Stachelin, T. and Gordon, J. (1979): Electrophoretic transfer of protein from poly acrylamide gels to nitrocellulose sheets, procedures and some application. Proc. Nati. Acd. Sci. USA., 76:4350-4354. 